\title{
Paleoecology explains Holocene chemical changes in lakes of the Nhecolândia (Pantanal-Brazil)
}

\author{
Renato Lada Guerreiro - Michael M. McGlue $\cdot$ Jeffery R. Stone • \\ Ivan Bergier - Mauro Parolin - Silane A. F. da Silva Caminha - Lucas V. Warren • \\ Mario L. Assine
}

Received: 2 August 2017/Revised: 30 October 2017/Accepted: 31 October 2017/Published online: 9 November 2017

(C) Springer International Publishing AG, part of Springer Nature 2017

\begin{abstract}
The objective of this research is to examine the history of lentic ecosystem salinity in the southern Pantanal wetlands (Brazil). The timing and controls on hydrochemical changes were inferred using sponge spicule and diatom paleoecology on a Holocene-aged sediment core from Nhecolândia, a lake district situated on a fossil lobe of the Taquari megafan. The oldest portion of the core contains Heterorotula fistula spicules, indicative of an ephemeral freshwater lake that existed until $\sim 4.6 \mathrm{cal} \mathrm{ka}$ BP. Benthic diatoms of the genus Gomphonema and Eunotia appeared $\sim 3.2 \mathrm{cal} \mathrm{ka} \mathrm{BP,} \mathrm{indicating} \mathrm{a}$
\end{abstract}

Handling editor: John M. Melack

R. L. Guerreiro $(\bowtie)$

Instituto Federal do Paraná - Campus Assis

Chateaubriand, 475 Avenida Cívica, Assis Chateaubriand,

Paraná CEP 85935-000, Brazil

e-mail: renato.guerreiro@ifpr.edu.br

M. M. McGlue

Department of Earth and Environmental Sciences,

University of Kentucky, 121 Washington Ave, Lexington, KY 40506, USA

\section{J. R. Stone}

Department of Earth and Environmental Systems, Indiana State University, 600 Chestnut Street, Terre Haute, IN 47809, USA

\section{Bergier}

Laboratory of Biomass Conversion, Embrapa Pantanal, CPAP, P.O. 109, Corumbá, MS, Brazil shallow and dystrophic environment. A transition to a more permanent lake that hosted freshwater sponges (e.g., Corvoheteromeyenia spp.), and diatom assemblages (e.g., Cyclotella meneghiniana, Aulacoseira pantanalensis) endured until $\sim 1.3$ cal year BP; after this time, most sponges and planktic diatoms disappear from the sedimentary record. High abundances of Anomoeoneis sphaerophora and Craticula guaykuruorum in the latest Holocene reflect a transition to a hyperalkaline, saline lake environment. The results suggest that Nhecolândia's saline lakes may evolve from freshwater precursors due to local (biochemical) and regional (geo-climatic) controls on water

\footnotetext{
M. Parolin

Laboratório de Estudos Paleoambientais da Fecilcam (Lepafe), Faculdade Estadual de Ciências e Letras de Campo Mourão, 733 Avenida Comendador Norberto Marcondes, Campo Mourão, Paraná CEP 87303-100, Brazil
}

S. A. F. da Silva Caminha

Laboratório de Palinologia de Mato Grosso, Faculdade de Geociências, Universidade Federal de Mato Grosso, 2367

Avenida Fernando Correia da Costa, Cuiabá,

Mato Grosso CEP 78060-900, Brazil

L. V. Warren - M. L. Assine

Instituto de Geociências e Ciências Exatas, Unesp -

Universidade Estadual Paulista, Avenida 24-A, Bela

Vista, Rio Claro, SP CEP 13506-900, Brazil 
availability, which has implications for patterns of biodiversity and ecosystems services in Pantanal.

Keywords Diatoms - Paleolimnology $\cdot$ Pantanal wetlands $\cdot$ Saline lakes $\cdot$ Sponge spicules

\section{Introduction}

The Pantanal wetlands form one of the most biodiverse ecosystems in the Neotropics (Por, 1995; Costa et al., 2015; Pott \& Silva, 2015). One control on the biodiversity in these wetlands is thought to be variability in the physical geography of the Pantanal Basin, which provides a rich mosaic of habitats for many different types of flora and fauna (Nunes da Cunha \& Junk, 2001; Evans \& Costa, 2013). An important early study by Assine \& Soares (2004) demonstrated that paleoenvironmental and geomorphological changes are the rule and not the exception in the Quaternary history of the Pantanal, in part due to the dynamics of climate interacting with the large rivers that comprise the basin. Indeed, climatic changes have been put forward to explain the low numbers of endemic species in the Pantanal, particularly with respect to plants adapted for sustained floodwater inundation (Junk et al., 2006). Nonetheless, fluvial hydrological and sedimentary processes control the form and function of the Pantanal wetlands as we understand them today (Assine et al., 2015a). At the macroscale, the wetlands cover $>140,000 \mathrm{~km}^{2}$ in west-central Brazil, and with smaller adjoining areas in Bolivia and Paraguay, comprise the largest savanna floodplain wetland on the planet (Fig. 1). The Upper Paraguay River, which runs along the western axis of the basin, typically floods in the austral summer (the "flood pulse" of Junk et al., 1989). The flood peak displaces north to south over several months, resulting in complex ecological interactions as waters crest channel banks and spread out over extensive heterogeneous floodplains (e.g., Girard et al., 2010). This process results in distinct zones within the Pantanal that exhibit different inundation periods, sedimentary environments, biogeochemical cycling, and habitat development (Hamilton et al., 1996; de Oliveira \& Calheiros, 2000; Marani \& Alvala, 2007; Alho, 2008; McGlue et al., 2011).
One of the largest sub-regions of the Pantanal is the Taquari River megafan, which occupies a central position in the basin (Fig. 1). The southern portion of the Taquari River megafan, known as Nhecolândia, is an abandoned depositional lobe marked by two contrasting landscapes (Zani et al., 2012). Upper (northeastern) Nhecolândia is a deeply furrowed landscape mantled with paleosols and ancient distributary channels, whereas Lower (southwestern) Nhecolândia contains myriad very small, circular to ellipsoidal, shallow lakes. Approximately $90 \%$ of these lakes are fresh (locally called baías), with the remainder being brackish and alkaline (locally called salinas). Both baías and salinas are surrounded to varying extents by $\sim 3-5 \mathrm{~m}$ elevated sandy ridges locally referred to as cordilheiras, but only the salinas are topographically closed and unaffected by local flooding during the wet season. Spatial variability in landforms, salinity, alkalinity, soil chemistry, and biological activity are high throughout the lake district of Lower Nhecolândia (Barbiéro et al., 2002; Furquim et al., 2010; Furian et al., 2013; Costa et al., 2015; Bergier et al., 2014). Yet the environmental history of this region remains understudied and in particular, the timing of salinization is poorly understood. A number of authors have suggested that paleoclimate, particularly prolonged aridity coupled with wind-driven erosion, may explain the existence of the Lower Nhecolândia lake district (e.g., Valverde, 1972; Klammer, 1982; Tricart, 1982; Clapperton, 1993; Assine et al., 2015b). Other authors have hypothesized that fluvial processes (i.e., channel incision and levee development) alone could explain the presence of these small lakes and their marginal sand hills (Ab'Sáber, 1988; Colinvaux et al., 2000). A recent study by McGlue et al. (2017) sampled three salinas from Nhecolândia, and concluded that deflation of the ancient megafan lobe during an arid early-middle Holocene was most consistent with lithofacies encountered in sediment cores.

McGlue et al. (2017) noted that the shallow stratal records of some salinas in Nhecolândia are relatively complete; these sediments archive environmental history with centennial-scale temporal resolution. That study interpreted, on the basis of vertical trends in carbon and opal chemostratigraphy and particle size variations that aquatic depositional environments varied through the late Holocene, with most bulk geochemical and sedimentological indicators pointing 


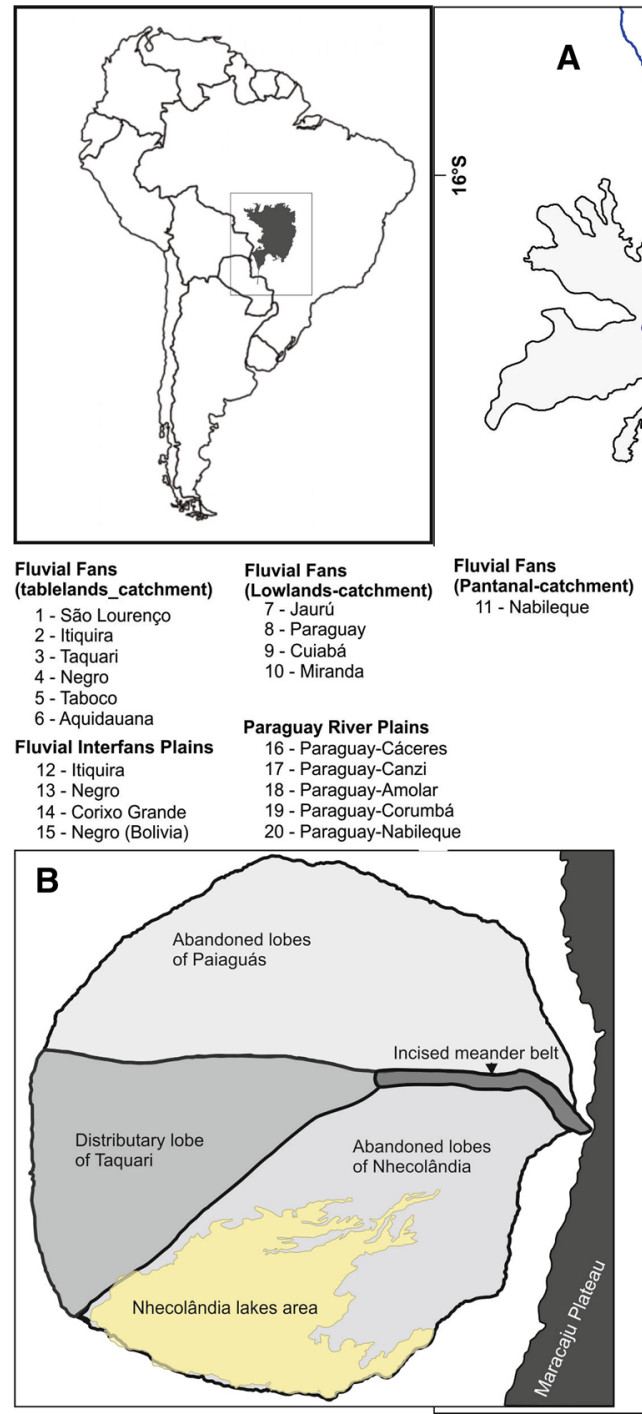

Fig. 1 Map of the Pantanal wetlands in the South American tropics. Inset map (upper left) shows the location of the Pantanal. A Depositional systems of the Pantanal Basin, marked by the presence of large distributary fluvial systems, including the Taquari megafan (after Assine et al., 2015b), with indication

towards the establishment of salinas as a relatively recent phenomenon. Here, we use highly sensitive biological indicators recovered from saline lake strata to test this idea, using a well-dated core from Salina da Ponta in northwest Nhecolândia. Taking advantage of improved chronological control (via new optically stimulated luminescence dates) and the discovery of a rich sponge spicule and diatom microfossil record, we address the history and timing of salinity changes. Our of the study area in Fig. 2. B Geomorphological compartments of the Taquari megafan (Zani et al., 2012; Costa et al., 2015). The lake district of Lower Nhecolândia is found on an abandoned fan lobe south of the modern Taquari River and the Paiaguás paleo-channel belt

approach merges an assessment of fossil diatom assemblages with sponge presence/absence and relative abundance data. Together, these bio-indicators are compared with modern analog ecosystems from the South American tropics, in order to reconstruct the environmental history of the lake ecosystem. This is the first study to use diatom and sponge paleoecology to trace Holocene paleolimnological changes in Nhecolândia. 


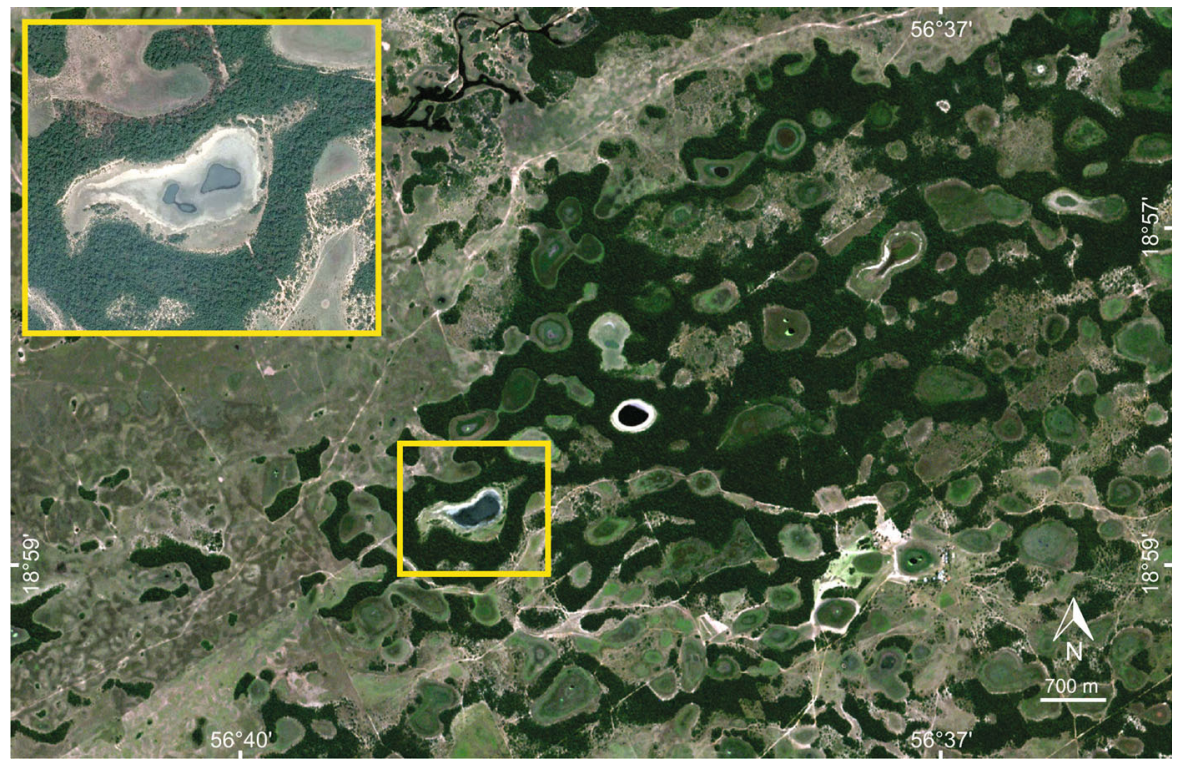

Fig. 2 Landsat TM images of Salina da Ponta in northwest Nhecolândia (yellow square), shown at both lake level highstand and lowstand (inset upper left). Marginal white sands are prominent along the lake margin. Cordilheiras appear as green (vegetated) areas surrounding the lake

Study area

The Pantanal Basin is a low-altitude, low-gradient, river-dominated landscape that covers parts of Mato Grosso and Mato Grosso do Sul states in western Brazil (Fig. 1). The Pantanal wetlands form within this tectonic basin due to the flooding of the Upper Paraguay River (Assine et al., 2015a). Flooding on the Upper Paraguay owes its existence to the arrival of seasonal rainfall in the northern Pantanal associated with the South American Summer Monsoon (SASM), which brings wet trade winds from the northeast Atlantic Ocean and the Amazon into the interior of Brazil (Zhou \& Lau, 1998). Today, the Pantanal experiences a tropical semi-humid climate with an average temperature of $25^{\circ} \mathrm{C}$ and well-defined wet and dry seasons. The average annual rainfall is $\sim 1100 \mathrm{~mm}$, which contrasts with evapotranspiration of $1400 \mathrm{~mm}$, promoting a regional water deficit of about $300 \mathrm{~mm}$. However, recent studies have shown that rainfall in the Pantanal has varied dramatically in the past (Novello et al., 2016, 2017). The cerrado (tropical savanna) biome is dominant in the study area, but differences in topography and flood dynamics have enabled diverse vegetation types to flourish. For instance, grassland and shrub vegetation occupy the low-lying areas subject to periodic flooding in Lower Nhecolândia, whereas dense stands of trees are common on the elevated cordilheiras where standing water is uncommon (Salis et al., 2014).

The $\sim 250-\mathrm{km}$-wide Taquari River megafan is one of the largest alluvial systems found anywhere in the world (Braun, 1977; Assine, 2005). Relief on the megafan is minimal, with altitudes of $\sim 85$ to $190 \mathrm{~m}$ above sea level. This results in a very gentle slope of $\sim 0.36 \mathrm{~m} / \mathrm{km}$ towards the regional base level provided by the Upper Paraguay River (Zani et al., 2012). Our study site is located on the ancient megafan lobe, whereas the active depositional lobe of the Taquari megafan is situated to the north of Nhecolândia. Nhecolândia is isolated from the direct influence of the Taquari River; the region's hydrology is controlled directly by rainfall, which feeds springs and effluent streams, and influences the elevation of the groundwater table (Assine et al., 2015c). During the rainy season, Nhecolândia is drained by a surface network of shallow tributary channels (locally named vazantes). The seasonal, freshwater baías are connected to this surface drainage network. In the rainy season, baías reach maximum depths up to $\sim 2 \mathrm{~m}$, but they frequently desiccate fully in the dry season (de Santos et al., 2012). The baías have $\mathrm{pH}$ values of 
$5-8$, low electrical conductivity (750-2000 $\mu \mathrm{S} / \mathrm{cm})$ and are covered by macrophytes (Barbiéro et al., 2002; Bergier et al., 2014). By contrast, Nhecolândia's salinas are isolated from seasonal floodwaters by the surrounding cordilheiras; these lakes rarely desiccate completely in the dry season. The salinas are marked by white sandy beaches, high $\mathrm{pH}(9-11)$, and high electrical conductivity $(500-65,000 \mu \mathrm{S} / \mathrm{cm})$. This extreme environment is unsuitable for aquatic macrophytes (Barbiéro et al., 2002). The presence of nonionizing forms of ammonia restricts biological diversity in the salinas (Mourão et al., 1988), except for alkaliphilic algae (e.g., certain diatom species), cyanobacteria, and archaea (de Santos \& Sant'anna, 2010; de Santos et al., 2012).

The study site, Salina da Ponta, is $\sim 0.14 \mathrm{~km}^{2}$ and it has an irregular elongate shape, making it similar to many of Lower Nhecolândia's salinas (Fig. 2). The lake water has a $\mathrm{pH}$ ranging between 9 and 10 and electrical conductivity varying from 556 to $5790 \mu \mathrm{S} /$ cm (Malone et al., 2007; Costa et al., 2015). The lake was initially selected for study because of its location on Nhumirim Farm, which is an experimental station maintained by the Brazilian Agricultural Research Corporation (EMBRAPA Pantanal). To our knowledge, Salina da Ponta is isolated from the direct influence of commercial ranching activities, which distinguishes it from many other salinas and baías in Nhecolândia. Further, preliminary research on the shallow stratigraphy of Salina da Ponta revealed a relatively complete temporal record for the latest Holocene, making sediments from this salina a strong candidate for more in-depth study (McGlue et al., 2017).

\section{Materials and methods}

Sediment core analysis and geochronology

Core NM1 ( $175 \mathrm{~cm}$ long) was collected from the center of Salina da Ponta in 2010 using a vibrocoring device. Sample collection, as well as initial description and photography in the laboratory, followed routine procedures for lake sediment cores (e.g., Schnurrenberger et al., 2003). The details of the lithostratigraphy and an initial radiocarbon $\left({ }^{14} \mathrm{C}\right)$ chronological model were reported in McGlue et al. (2017). Here, we improve upon this ${ }^{14} \mathrm{C}$ chronology of the NM1 core by integrating two optically stimulated luminescence (OSL) ages from sandy horizons at $\sim 97$ and $\sim 170 \mathrm{~cm}$ below lake floor (cm blf), into the age-depth statistical model. The OSL ages were determined at the University of São Paulo using standard techniques. Briefly, the OSL method is based on the single aliquot dose concept and it functions by treating quartz grains as dosimeters, which record low amounts of ionizing ambient radiation (Aitken, 1985; Murray \& Wintle, 2003). Sediment samples from NM1 were collected in a dark room to avoid exposure to sunlight, then wet sieved to $63-125 \mu \mathrm{m}$, treated with $\mathrm{HCl}, \mathrm{H}_{2} \mathrm{O}_{2}$, and $\mathrm{HF}$, and subjected to heavy liquid separation in order to isolate quartz grains (Sawakuchi et al., 2016). Sample aliquots were bleached for 3-5 h, preheated to $200^{\circ} \mathrm{C}$, and delivered a 25 Gy dose using a Ris $\varnothing$ TL/OSL DA-20 with $\mathrm{Sr} / \mathrm{Y}$ beta radiation source, in order to determine the OSL age (using the central age model of Galbraith et al., 1999). All ${ }^{14} \mathrm{C}$ and OSL data used in our age model appear in Tables 1 and 2. We used the program BACON for R, a

Table 1 Radiocarbon dates used in the development of the age-depth model for core NM1

\begin{tabular}{|c|c|c|c|c|c|c|}
\hline Lab number & $\begin{array}{l}\text { NM1 depth } \\
(\mathrm{cm})\end{array}$ & $\delta^{13} \mathrm{C}(\%)$ & $\begin{array}{l}\text { Conventional age } \\
\left({ }^{14} \mathrm{C} \text { year } \mathrm{BP}\right)\end{array}$ & Error & $\begin{array}{l}\text { Median age } \\
\text { (cal year BP) }\end{array}$ & $\begin{array}{l}2-\sigma \text { range } \\
(\text { cal year BP) }\end{array}$ \\
\hline Beta 417761 & 1 & -21.3 & $104.8 \mathrm{pMC}$ & 0.3 & 70 & $35-105$ \\
\hline Beta 429478 & 20 & -21.3 & 850 & 30 & 720 & $670-790$ \\
\hline Beta 353950 & 30 & -20.6 & 1030 & 30 & 890 & 790-1010 \\
\hline Beta 429479 & 43 & -21.5 & 1670 & 30 & 1500 & $1380-1670$ \\
\hline Beta 403549 & 50 & -18.5 & 2300 & 30 & 2160 & $1940-2360$ \\
\hline Beta 427472 & 60 & -18.9 & 3080 & 30 & 3220 & $2970-3400$ \\
\hline Beta 427473 & 67 & -17.7 & 3460 & 30 & 3630 & $3470-3770$ \\
\hline Beta 353952 & 75 & -19.0 & 3510 & 30 & 3830 & $3680-4020$ \\
\hline
\end{tabular}




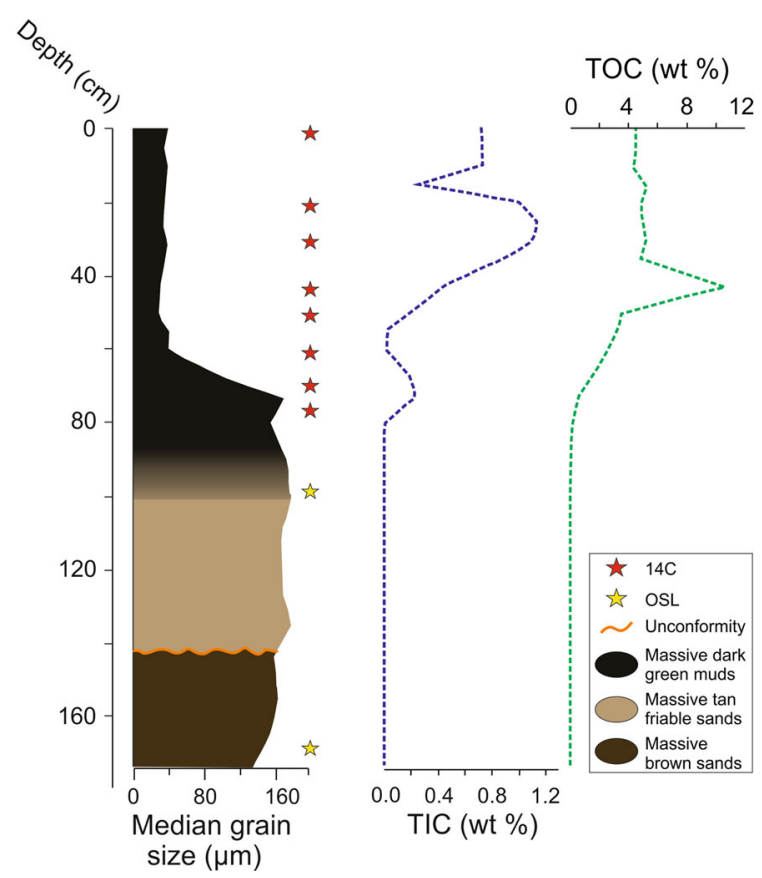

Fig. 3 Core NM1, extracted from the center of Salina da Ponta. The stratigraphy consists of indurated, massive dark brown sands underlying friable tan sands and dark green muds. Median grain size, total inorganic carbon (TIC), and total organic carbon (TOC) data from McGlue et al. (2017). Stars mark the locations of radiocarbon and optically stimulated luminescence dates

Bayesian statistical software package that estimates sediment accumulation rates through millions of Monte Carlo Markov Chain iterations, in order to produce an integrated ${ }^{14} \mathrm{C}$ and OSL age-depth model for NM1 (Blaauw \& Cristen, 2011). The ${ }^{14} \mathrm{C}$ dates were calibrated using SHCal13, and the post-bomb date at $1 \mathrm{~cm}$ blf was calibrated using the $\mathrm{SH} 3$ postbomb calibration curve (Hogg et al., 2013; Hua et al., 2013). The advantage of Bayesian modeling for agedepth pair construction is that prior information concerning hiatuses and accumulation rates, modeled as gamma distributions, can be accounted for in the analysis. Several assumptions were built into the BACON model, including: (a) the presence of a prolonged hiatus (5500 years) at the sharp and irregular-looking contact between basal brown indurated sands and overlying tan friable sands at $145 \mathrm{~cm}$ blf (Fig. 3), (b) an accumulation rate mean of 100 years/ $\mathrm{cm}$, (c) default values for accumulation rate memory and strength, and (d) an alternative maximum depth of $200 \mathrm{~cm}$, such that the model projects beyond the 
lowermost OSL date and produces a full range of potential ages for the base of the core.

Sponges

Sediment samples $(n=22)$ were individually boiled in $65 \% \mathrm{HNO}_{3}$ and washed several times with distilled water and $70 \%$ alcohol, and centrifuged to isolate sponge remains. The resulting material was pipetted onto a glass slide, covered with Entellan ${ }^{\circledR}$ resin and a coverslip, and analyzed under an optical stereomicroscope (Volkmer-Ribeiro \& Turcq, 1996). Sponge spicules were photographed and classified according to the three categories described by Volkmer-Ribeiro \& Pauls (2000), including: (i) megascleres, (ii) microscleres, and (iii) gemmoscleres, which tend to be the most significant skeletal elements used in species identification. The spicules were identified based on a reference collection housed at the Laboratório de Estudos Paleoambientais da Fecilcam, the World Porifera Database (van Soest et al., 2017), and using the published guides of Bonetto \& Ezcurra de Drago (1966), Ezcurra de Drago (1974, 1979), Volkmer-Ribeiro \& Motta (1995), and Volkmer-Ribeiro et al. (1992, 1998). Results of the sponge spicule analysis are presented as presence versus absence and relative abundance data. We adopted the relative abundance categories of 'very rare,' 'rare,' 'common,' and 'abundant,' according to Racek (1974). Paleoenvironmental characterization based on sponge fossils follows the method of modern analogs, which takes into account the environmental conditions where living specimens have been documented (Debrot \& van Soest, 2001; Volkmer-Ribeiro \& Machado, 2007; Parolin et al., 2008; Volkmer-Ribeiro \& Parolin, 2010; Machado et al., 2012; Kuerten et al., 2013). We also utilized the "spongofacies" method described by Parolin et al. (2008) in our interpretative framework. Spongofacies are intervals where a single sponge species or species assemblage dominates, facilitating a paleoenvironmental interpretation from these microfossils alone (Parolin et al., 2008).

\section{Diatoms}

Sediment samples $(n=14)$ were analyzed for diatoms at Indiana State University. Dry sediment sub-samples were weighed into scintillation vials and treated with $35 \% \mathrm{H}_{2} \mathrm{O}_{2}$ at room temperature for three weeks to digest organic material. Supernatant fluids were removed with an aspirator and samples were rinsed with reverse osmosis purified water four times. Known quantities of polystyrene microspheres were added to estimate diatom concentrations (Battarbee et al., 2001); diatom extractions were then dried onto number-1 type coverslips and mounted onto microscope slides with Zrax, a permanent high-refractive index medium. The slides were analyzed at $1000 \times$ magnification with a transmitted light microscope (Leica DM2500) under differential interference contrast optical illumination. Diatom frustules were identified to the most specific taxonomic level possible, following the taxonomy of Metzeltin \& LangeBertalot (2007), Malone et al. (2012), de Santos et al. (2012), Morales et al. (2014), and Tremarin et al. (2014) as the primary resources. When possible, at least 300 diatom valves were identified from each sample interval. Constrained clustering with Euclidean distance was performed on square-root transformed diatom data using the R package rioja v. 0.9-9 (Juggins, 2016). Significance of constrained clusters was determined using the Broken Stick method.

\section{Results}

Age model

The integrated ${ }^{14} \mathrm{C}$ and OSL-based age model for NM1 appears in Fig. 4. Predictably, the undated base of the core has the widest 2- $\sigma$ error range and falls between $\sim 28.6$ and $\sim 14.1$ cal ka BP, with a median age of $\sim 20.8 \mathrm{cal} \mathrm{ka} \mathrm{BP.} \mathrm{Sediments} \mathrm{underlying}$ the hiatus at $145 \mathrm{~cm}$ blf return a median age of $\sim 17.7 \mathrm{cal} \mathrm{ka} \mathrm{BP,}$ whereas sediments just above this contact have a median age of $\sim 11.4$ cal ka BP. Thus, more than $6000 \mathrm{yrs}$ of the late Pleistocene deglacial period is likely missing from NM1. The most reliably dated interval of NM1, constrained by nine dates and a strong model fit, is the upper $\sim 100 \mathrm{~cm}$ (Fig. 4). This section represents the last $\sim 6.8 \pm 1.3 \mathrm{cal} \mathrm{ka}$, with resolution decreasing with increasing depth. The contact between basal sandy sediments and upper muddy sediments (Units 1 and 2, respectively, of McGlue et al., 2017) returned a median age of $\sim 3.2 \pm 0.18$ cal ka BP. 

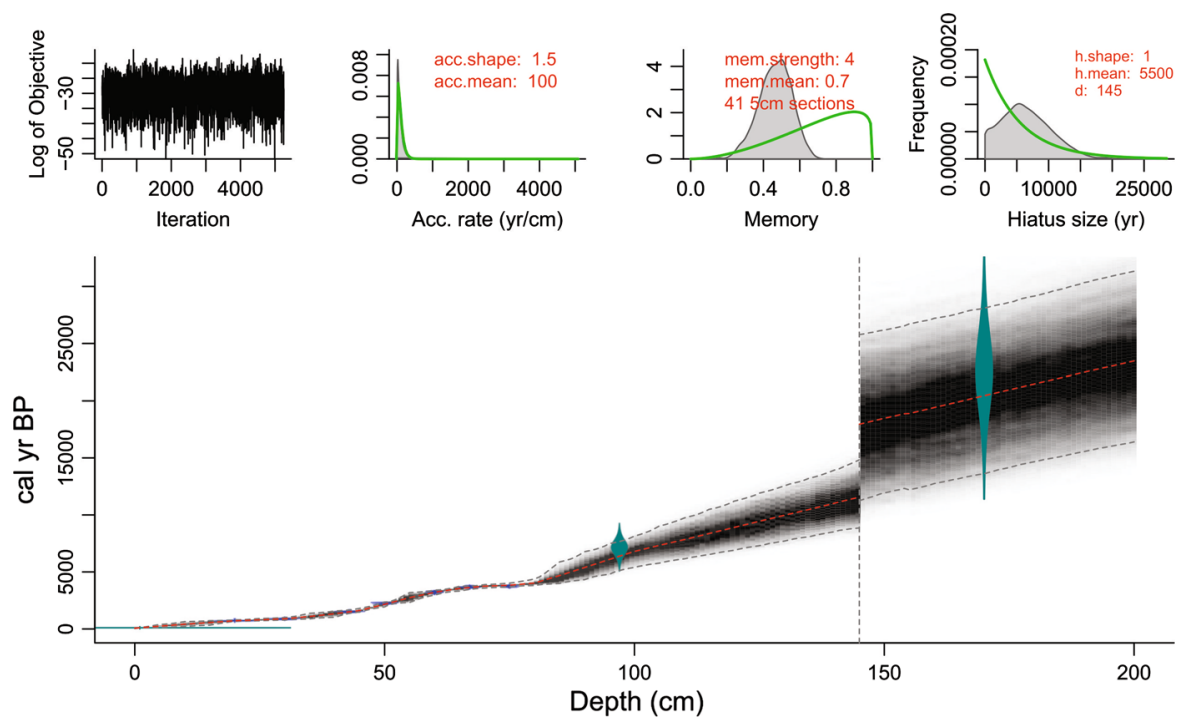

Fig. 4 BACON-derived age-depth model for Salina da Ponta core NM1, encompassing all radiocarbon and optically stimulated luminescence dates. The position of the unconformity at $\sim 145 \mathrm{~cm}$ was interpreted based on sedimentological

\section{Sponges}

Pleistocene-age, brown cohesive sands below the interpreted unconformity were largely absent of siliceous microfossils and therefore considered paleontologically sterile; these sediments will not be considered further. By comparison, the friable tan sandy sediments representing the early-middle Holocene contained abundant sponge microfossils (Figs. 5 and 6). In these beds, spicules were present but heavily fragmented, in most cases preventing species classification. An exception is the presence of Heterorotula fistula Volkmer-Ribeiro \& Motta, 1995. Gemmoscleres of $H$. fistula are present in low abundance from $\sim 11.0$ to $4.6 \mathrm{cal} \mathrm{ka} \mathrm{BP}$. The disappearance of H. fistula spicules coincides with the appearance of Corvoheteromeyenia Ezcurra de Drago, 1979 and Heteromeyenia Potts, 1881 species spicules and the transition from tan friable sands into dark green, carbon-rich sediments in core NM1 (Fig. 3). Gemmoscleres and microscleres of Corvoheteromeyenia spp. are common to abundant from $\sim 4.6$ to $3.2 \mathrm{cal} \mathrm{ka} \mathrm{BP}$ and form a spongofacies. Corvoheteromeyenia spp. spicules and rare gemmoscleres of Heteromeyenia spp. occur together from $\sim 3.6$ to $1.0 \mathrm{cal} \mathrm{ka} \mathrm{BP}$. After this time, the abundance of spicules declines, but rare gemmoscleres of Ephydatia characteristics of the core. Indurated Pleistocene sands below the unconformity are paleontologically sterile, whereas friable tan sands and green muds above the unconformity contain siliceous microfossils

Lamouroux, 1816 persist in the sediments until $\sim 1.0 \mathrm{cal} \mathrm{ka} \mathrm{BP.} \mathrm{Sponge} \mathrm{microfossils} \mathrm{are} \mathrm{com-}$ pletely absent in the record from $890 \mathrm{cal}$ year BP until present.

\section{Diatoms}

Fossil diatom assemblages were an abundant component of the sediment throughout the upper $\sim 67 \mathrm{~cm}$ blf ( $\sim 3.6 \pm 0.17 \mathrm{cal} \mathrm{ka} \mathrm{BP})$ of the core; diatoms are absent from older tan sands situated above the hiatus. Diatom assemblages throughout this section cluster (Fig. 7) into two distinct, statistically significant groups, Diatom Zone 1 (DZ1) and Diatom Zone 2 (DZ2), differentiated at approximately $\sim 1.3 \mathrm{cal} \mathrm{ka}$ BP.

DZ1 ( 3.6 to 1.3 cal ka BP) can be further subdivided into two sub-zones with broadly similar diatom fossil assemblages. The lower is characterized by high relative abundances of benthic diatoms belonging to Gomphonema (G. gracile, G. parvulum, G. turris f. coarctata) and Eunotia cf. spectabilis (Figs. 7 and 8). Several Nitzschia species occur throughout the core, but typically in abundances $<10 \%$. Only one planktic diatom is common in the lower sub-zone, Cyclotella meneghiniana Kützing, typically occurring in relative 
Fig. 5 Sponge paleoecology for Salina da Ponta, based on relative abundances. 0 Absent. 1 Very rare. 2 Rare. 3 Common. 4 Abundant
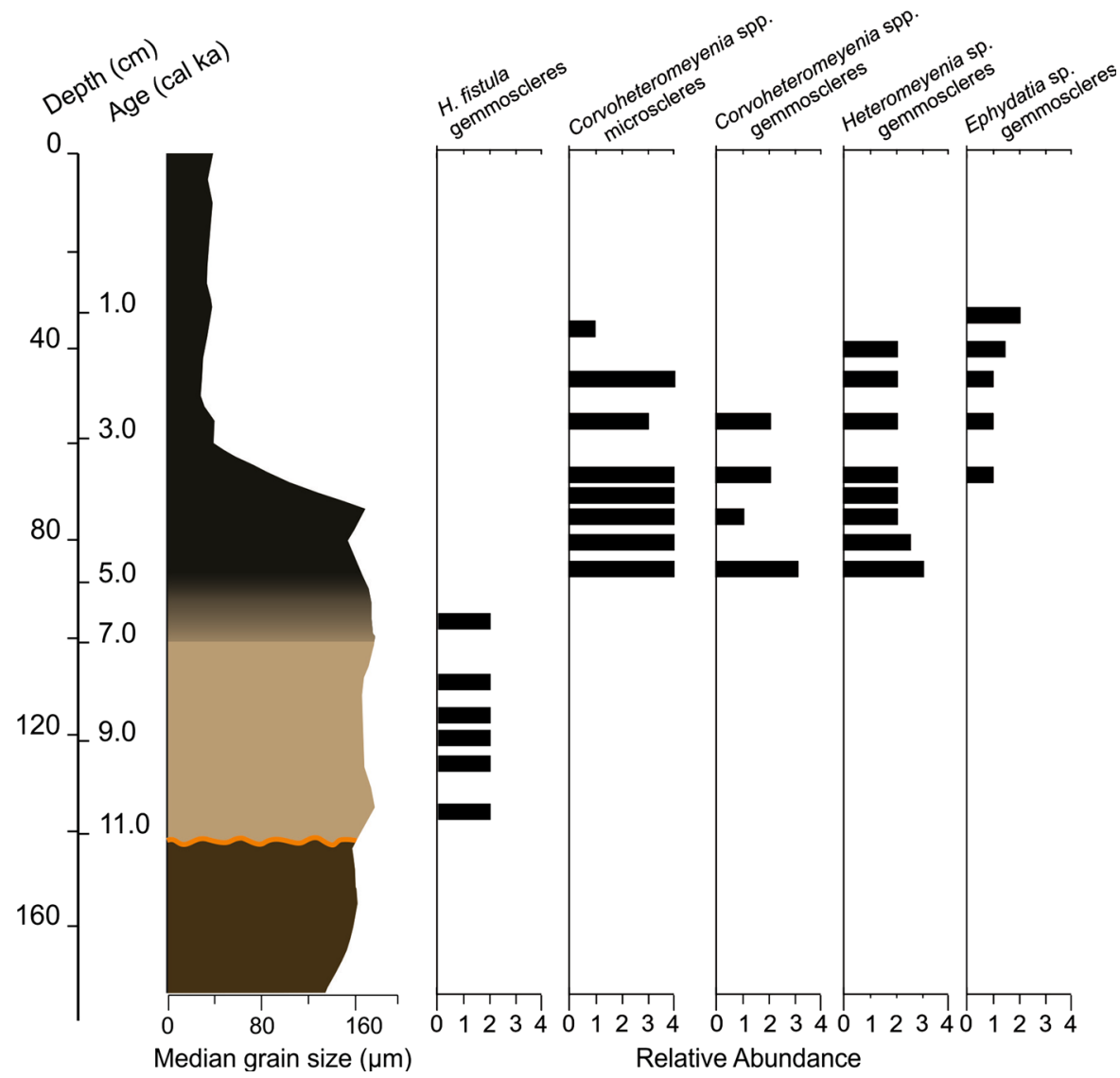

abundances $<10 \%$ of the total assemblage. The upper sub-zone of DZ1 ( 2.2 to 1.3 cal ka BP) is defined by a substantial increase in planktic diatoms. This is especially apparent in $C$. meneghiniana, which increases to represent slightly less than half of all total assemblages throughout this section of the core. A second planktic taxon, Aulacoseira pantanalensis Tremarin, Torgan \& Ludwig, 2014, also occurs commonly (10-20\%) in the fossil assemblages of this sub-zone. Benthic species have essentially the same composition as in the lower sub-zone, but all common benthic species from the lower sub-zone become considerably rarer.

DZ2 ( 1.3 cal ka BP-present) is marked by a distinct change in the diatom assemblages, including considerably higher relative abundances of Anomoeoneis sphaerophora Pfitzer (20-40\%) and Craticula guaykuruorum Wetzel, Morales \& Ector (40-80\%), which were previously very rare components of the fossil diatom assemblages in DZ1. Planktic species that were common in the upper sub-zone of DZ1 rapidly disappear and are insignificant components of all assemblages in DZ2.

\section{Discussion}

NM1 chronology

The addition of OSL ages at the base of the NM1 core enabled us to understand the likely length and continuity of deposition at Salina da Ponta in the late Quaternary. Paleoenvironmental analysis for the late Pleistocene in Pantanal has been constrained by a paucity of lacustrine records of sufficient length and temporal resolution to assess major changes in hydroclimate (McGlue et al., 2015). Recently, oxygen isotope records from very well-dated speleothems collected from a cave on the southeastern Pantanal margin revealed compelling evidence for a wet last glacial period from $\sim 27.8$ to $17.8 \mathrm{ka} \mathrm{BP}$ (Novello et al., 2017), which contrasts with findings from lake- 

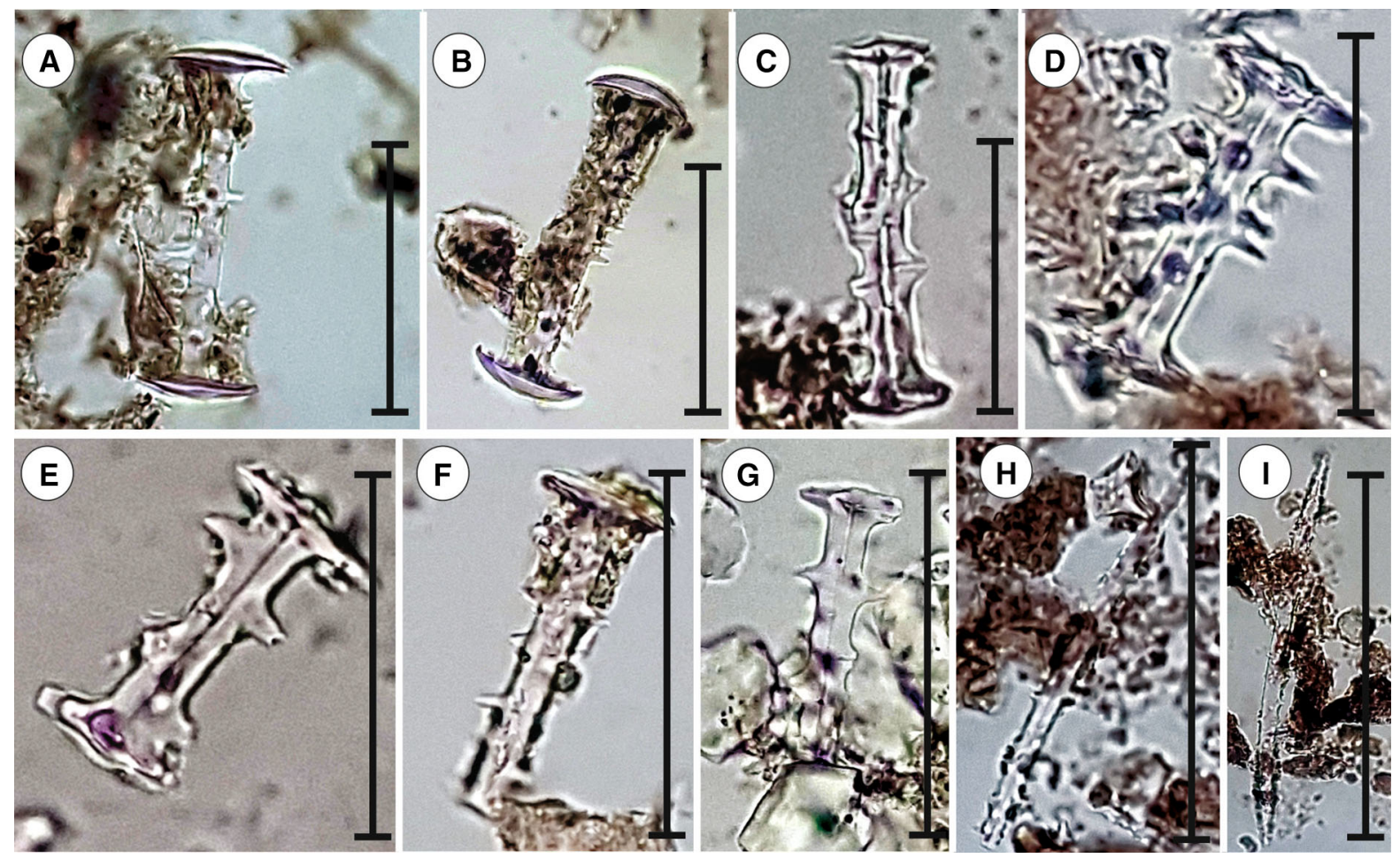

Fig. 6 Photomicrographs of sponge spicules recovered in Salina da Ponta sediments. A, B Gemmoscleres of Corvoheteromeyenia spp. Corvoheteromeyenia spp. sponges are known to inhabit ephemeral and permanent shallow freshwater lakes in the Neotropics. C H. fistula gemmosclere. Ephydatia spp. gemmosclere. H. fistula are typically encountered in

ephemeral lakes in semi-arid environments, whereas Ephydatia spp. have been found in brackish water bodies. D Heteromeyenia spp. gemmosclere. E, F Gemmosclere fragments of Heteromeyenia and Ephydatia spp. G Microscleres of Heteromeyenia spp. All scale bars are $25 \mu \mathrm{m}$

based records (Whitney et al., 2011). The indurated, glacial-aged brown sands that are barren of identifiable fossils below the unconformity are consistent with a fluvial environment when the climate of the Lower Nhecolândia was wetter. The speleothem record of Novello et al. (2017) also revealed abrupt increases in rainfall during Heinrich Stadial 2 (24.7-23.8 ka BP), Heinrich Stadial 1 (17.7-16.8 and 16.0-14.8 ka BP), and the Younger Dryas (12.9-11.6 ka BP). These abrupt wet events may explain the presence of the deglacial-age hiatus in NM1, but additional dating and cores from multiple lakes are required to fully verify this possibility. Most importantly, the Holocene section appears to be relatively complete in Salina da Ponta, particularly from $\sim 6.8 \pm 1.3 \mathrm{cal} \mathrm{ka}$ BP. Unlike larger lakes directly connected to the Upper Paraguay River (McGlue et al., 2012), the linearity of our age-depth model suggests it is unlikely there were long-lasting

hiatuses at the transition from the middle to late Holocene at Salina da Ponta. This finding allows us to reliably use sponge and diatom paleoecological insights to infer climate change patterns for Nhecolândia, and to test hypotheses related to changes in depositional environment put forward in a previous study (McGlue et al., 2017).

Sponge and diatom paleoecology

Freshwater sponges are sessile animals of the Phylum Porifera, Class Demospongiae, and they are found in both ephemeral and permanent rivers, lakes, and mixohaline coastal ecosystems (Manconi \& Pronzato, 2007). Plates of spongina enveloped by siliceous spicules bind the animal to a submerged substrate, which can be dead plants, rock surfaces, living macrophyte roots, and tree trunks. Depending on environmental and hydrological conditions, sponges 


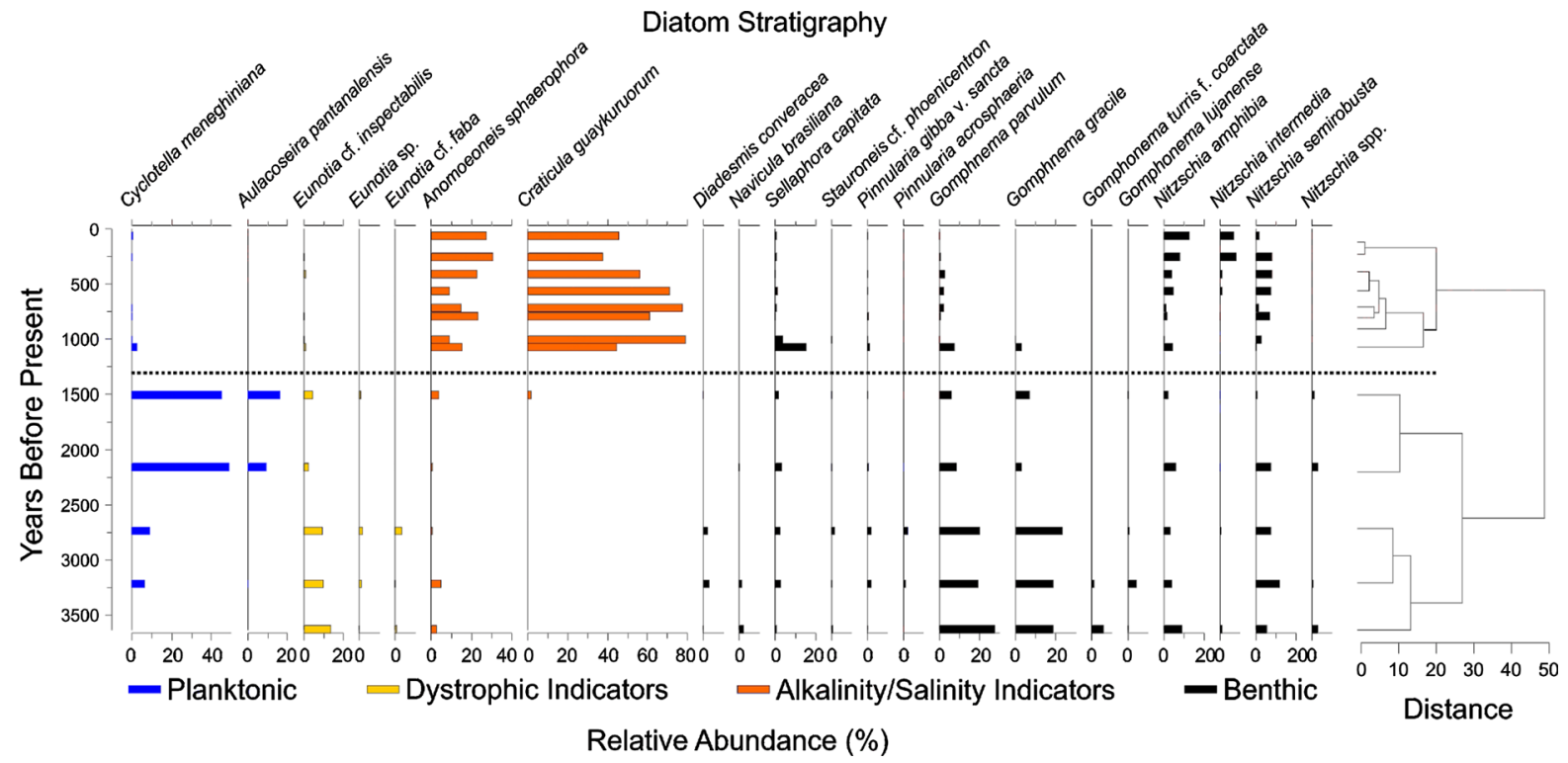

Fig. 7 Diatom stratigraphy of core NM1. The dashed line marks the boundary between freshwater environments in Diatom Zone 1 ( 3.6 to $1.3 \mathrm{cal} \mathrm{ka} \mathrm{BP})$ and saline/alkaline environments in Diatom Zone 2 ( 1.3 cal ka BP to present).

may reproduce sexually or asexually (Manconi \& Pronzato, 2002; Volkmer-Ribeiro \& Parolin, 2010). Sexual reproduction is favored in stable aquatic environments, and allows for species dispersion through the release of free-swimming larvae (Volkmer-Ribeiro \& Parolin, 2010). Fluctuating aquatic environments tend to promote asexual reproduction by a release of gemmules comprised of totipotent cell sets, allowing the organism to self-replicate even under harsh environmental conditions such as extreme droughts that fully desiccate the aquatic ecosystem (VolkmerRibeiro \& Parolin, 2010). As components of gemmules, siliceous gemmoscleres are likewise released during asexual reproduction, and provide a means for identification of sponge species, as well as insights on water column residence time (Manconi \& Pronzato, 2002).

The sponge spicules encountered in NM1 have been described in both modern aquatic settings and ancient deposits, which provides context for our paleoenvironmental interpretations. The presence of H. fistula gemmoscleres in NM1 from $\sim 11.0$ to 4.6 cal ka BP suggests a fluctuating lentic environment. We interpret sediments with $H$. fistula spicules to reflect a low-conductivity ephemeral lake.
Diatom species used to infer distinct environmental conditions are noted in the legend at the base of the figure. See text for details

Pronounced fragmentation of $H$. fistula spicules suggests the potential for reworking of the lake floor, perhaps during periods of subaerial exposure, through the activity of bioturbating organisms, or by erosive flood flows or wind scouring. This suggests a lake with a short residence time and highly variable water levels; this interpretation is consistent with the absence of fine-grained sediment in this section of the core. Further, this interpretation is consistent with occurrences of Heterorotula spp. sponges found in ephemeral lakes in semi-arid regions of Australia (Racek, 1969; De Deckker, 1983). Volkmer-Ribeiro \& Motta (1995) and Volkmer-Ribeiro et al. (1998) have suggested that Heterorotula are common components of spongilites that represent lacustrine environments conditioned by seasonal precipitation and long dry seasons. Following those authors, the presence of $H$. fistula in late Quaternary sediments in Brazil has consistently been associated with lakes influenced by a seasonally dry climate (Parolin et al., 2007; Kuerten et al., 2013). Therefore, the weight of evidence strongly suggests that a freshwater lake with a short residence time and highly variable water levels prevailed at Salina da Ponta from $\sim 11.0$ to 4.6 cal ka BP. 

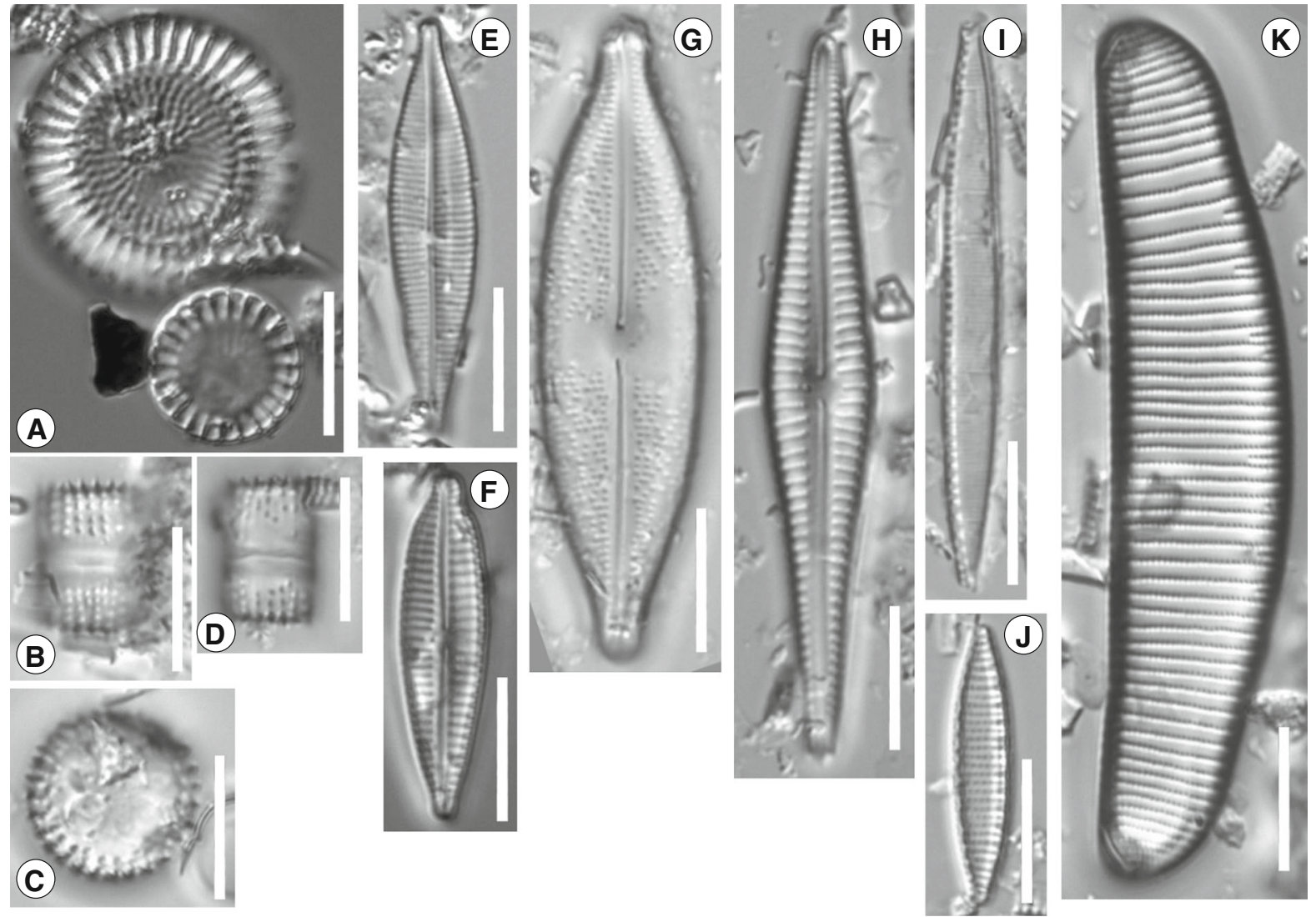

Fig. 8 Major diatom flora of Core NM1. A Cyclotella meneghiniana. B, C, D Aulacoseira panatanalensis. E Craticula guaykurourum. F Gomphonema parvulum. G Anomoeoneis

We infer that an aquatic transition initiated with the appearance of Corvoheteromeyenia spp. spicules at $\sim 4.6 \pm 1.3 \mathrm{cal} \mathrm{ka} \mathrm{BP}$. This timing is significant, because it precedes the most significant lithological transition in the core, based on detrital particle size and total carbon chemostratigraphy, which show a relatively abrupt change occurring at $\sim 3.2 \pm 0.18$ cal ka BP (McGlue et al., 2017). This indicates that the sponge fauna were sensitive to progressive changes in environmental conditions. The genus Corvoheteromeyenia is endemic to the Neotropics and its known habitat is freshwater lakes (Volkmer-Ribeiro et al., 1999). Corvoheteromeyenia spp. sponges have been recorded in the ephemeral inter-dune freshwater lakes of the Lençóis Maranhenses National Park (northern Brazil) and in fresh lakes of northern Venezuela and Curaçao (Volkmer-Ribeiro et al., 1999; Debrot \& van Soest, sphaerophora. H Gomphonema gracile. I Nitzschia intermedia. J Nitzschia amphibia. K Eunotia cf. inspectabilis. All scale bars are $10 \mu \mathrm{m}$

2001; Tavares et al., 2003; Volkmer-Ribeiro \& Pauls, 2000). This is broadly consistent with the environmental conditions interpreted for $H$. fistula-rich sediments, though it is clear that the hydrodynamic energy of this setting must have declined because of slight increases in silt, clay, and organic carbon content (McGlue et al., 2017). Thus, we infer that water column stability and residence time in Salina da Ponta started to increase, and benthic habitats were changing around $\sim 4.6 \mathrm{cal} \mathrm{ka}$ $\mathrm{BP}$, as Corvoheteromeyenia and Heteromeyenia spp. replaced Heterorotula in Salina da Ponta. Notably, rare to common gemmoscleres and abundant microscleres of both Corvoheteromeyenia and Heteromeyenia spp. mark the record from $\sim 4.6$ to 3.2 cal ka BP, whereas exclusively microscleres appear in varying abundances in sediments $\sim 2.7-0.89 \mathrm{cal} \mathrm{ka} \mathrm{BP}$. We interpret the loss of Corvoheteromeyenia spp. and Heteromeyenia 
spp. gemmoscleres to reflect greater water column stability, since microscleres, the small spicules usually found on the surface of sponges, are commonly lost to taphonomic damage in lakes with high-frequency changes in water level (Guerreiro et al., 2013; Kuerten et al., 2013).

The collapse of the sponge community at $\sim 890 \pm 115$ cal year BP is not coeval with a strong lithological or geochemical boundary. Sediments above and below the last appearance of sponges are massive, dark green, organic-rich clayey silts. Taken together, these observations suggest that the disappearance of the sponge spicules is not related to lake desiccation. Rather, we posit that the sponge decline and diatom proliferation after $\sim 890$ cal year BP was the result of a pronounced change in water chemistry favoring highly saline, alkaline conditions similar to the present day environment. In fact, the occurrence of Ephydatia spp. spicules may indicate a transition to a saline environment, since species of this genus are found in organic-rich environments with slightly brackish water (Volkmer-Ribeiro et al., 2004, 2007).

The most common diatoms in the lower sub-zone of DZ1 ( 3.6 to 2.2 cal ka BP) are common in benthic habitats; most of the benthic species are found in slightly acidic to circumneutral ( $\mathrm{pH}$ 5-7.8) waters with relatively low to moderate conductivities (de Santos et al., 2012). Low abundances of planktic diatoms and the dominance of species common in periphyton and metaphyton suggest that the lake during this period was part of a relatively fresh, shallow-water system, with multiple sunlit substrates to act as attachment points for mucilaginous stalked diatoms, such as Gomphonema. Moderate relative abundances of several Eunotia species suggest a moderately dystrophic environment, which may have supported high colonization of the lake by aquatic macrophytes. These characteristics are typical of what is encountered in Nhecolândia's baías today. We infer the substantial increase in planktic diatoms, which dominate the upper sub-zone of DZ1 ( 2.2 to 1.3 cal ka BP), to generally represent a relatively deeper-water environment. C. meneghiniana is a common component of many slow-flowing river systems, particularly when nutrients are elevated (Houk et al., 2010) and lakes where salinity frequently fluctuates substantially between fresh and brackish conditions (Fritz et al., 1993; Tapia et al., 2003). A. pantanalensis, which becomes common in the upper sub-zone of DZ1, is found in eutrophic waters in modern settings (Tremarin et al., 2014), which supports that idea that nutrient loading of the lake was greater during this period, potentially as a result of increased inundation by flood waters with high concentrations of solutes.

The stark contrast between diatom assemblages recovered from DZ1 and DZ2 indicates a change of the local hydrodynamics of this system. The disappearance of the planktic species, which are replaced by two benthic diatoms (A. sphaerophora and C. guaykuruorum) capable of living in hyperalkaline, brackish water conditions (de Santos et al., 2012; Malone et al., 2012; Morales et al., 2014), suggests that the lake water may have declined significantly, concomitant with a substantial rise in $\mathrm{pH}$ and salinity. These two species are common throughout the modern aquatic environments of the Pantanal region, likely because they are particularly adapted to surviving across a much wider range of environmental conditions, but can become dominant during the dry season (de Santos et al., 2012).

\section{Hydrochemical and climatic changes}

Integration of the biological indicators examined in this study suggests a three-phase evolution of the aquatic ecosystem at Salina da Ponta in the Holocene: (i) an ephemeral freshwater lake phase from $\sim 11.0$ to $4.6 \mathrm{cal} \mathrm{ka} \mathrm{BP}$, (ii) a more stable, deeper freshwater lake phase from $\sim 3.2$ to $1.3 \mathrm{cal} \mathrm{ka} \mathrm{BP}$, and (iii) an alkaline/saline lake phase from $\sim 1.3 \mathrm{cal} \mathrm{ka} \mathrm{BP}$ to present, which became strongly alkaline by $\sim 890$ cal year BP. We posit that these environmental changes were modulated by local (biochemical processes interacting with floodplain landforms) and regional (climate) forcings.

The early-middle Holocene ephemeral freshwater lake phase is consistent with a dry climate, owing to low southern hemisphere insolation at the latitude of the Pantanal at that time (Mayle et al., 2000; Whitney et al., 2011). The known modern distribution and habitat preferences of Heterorotula, spicule morphology, and spicule preservation all strongly point towards an aquatic environment with a short residence time, influenced by extended dry seasons and low effective precipitation. This arid environment may have helped produce the Nhecolândia landscape itself, as sedimentary facies data suggest that deflation of 
sands on the ancient megafan lobe played a role in developing the space necessary to accommodate lakes (McGlue et al., 2017). Sponge data, contextualized by the revised NM1 chronology, confirm that Salina da Ponta did not form during the Last Glacial Maximum, as had been hypothesized by some earlier researchers (Tricart, 1982; Clapperton, 1993).

The transition from an ephemeral to a more permanent freshwater lake appears to have been a gradual process in Nhecolândia. The sponge record indicates that Corvoheteromeyenia and Heteromeyenia spp. replaced Heterorotula in Salina da Ponta at $\sim 4.6 \pm 1.3 \mathrm{cal} \mathrm{ka} \mathrm{BP,} \mathrm{but} \mathrm{the} \mathrm{presence} \mathrm{of} \mathrm{gem-}$ moscleres suggests that water levels remained somewhat variable until $\sim 3.2 \mathrm{cal} \mathrm{ka} \mathrm{BP}$. This result is consistent with NM1 lithofacies, as the accumulation of dominantly fine-grained, organic-rich lake muds did not commence until 3.2 cal ka (Fig. 3) (McGlue et al., 2017). An increase in the ratio of planktic to benthic diatoms in the upper sub-zone of DZ1 provides the best fossil evidence in our dataset for a considerable increase in rainfall and higher water levels in this lake, which occurred starting around $2.2 \pm 0.2$ cal ka BP. By that time, microscleres of Corvoheteromeyenia and Heteromeyenia were present in the sediments, which suggests an increase in lake water residence time. Organic carbon concentrations and $\mathrm{C}: \mathrm{N}$ increase to near maximum values in the record after the lake level rose, accompanied by a decrease in sedimentation rate (McGlue et al., 2017). A progressive increase in regional effective precipitation best explains the evolution of the stable freshwater lake. Many paleolimnological and cave records from the Pantanal and elsewhere in the South American tropics bear witness to a late Holocene recovery from a drier climate (Fornace et al., 2016) that is consistent with our observations from Salina da Ponta.

The alkaline and saline lake phase that commenced around $1.3 \mathrm{cal} \mathrm{ka}$ BP is interpreted to have evolved due to both local and regional factors. The diatom record at that time was dominated by A. sphaerophora and $C$. guaykuruorum, while carbonate content attained maximum concentrations in NM1 sediments (McGlue et al., 2017). Sponge spicules are notably absent, which is best explained by their ecology and known environmental tolerances. Debrot \& van Soest (2001) stated that Corvoheteromeyenia have been encountered in waters with a maximum $\mathrm{pH}$ of $\sim 8.1$, moderate electrical conductivity $(2075 \mu \mathrm{S} / \mathrm{m})$, and low salinity. However, our diatom data make clear that $\mathrm{pH}$ and salinity levels likely became too extreme for sponges. Intriguingly, the best dated paleoclimate archives from the Pantanal show that this interval was marked by some significant wet periods, including the Little Ice Age (1600-1820 AD) (Novello et al., 2017). In fact, most climate proxy records developed from the Pantanal's floodplain lakes and caves suggest higher rainfall over the last 1000 years (Bertaux et al., 2002; McGlue et al., 2012). Modern hydrogeochemical datasets provide insights into local controls specific to Lower Nhecolândia. For example, salinity patterns have been attributed to the isolation of lake basins from overland flows during seasonal floods by cordilheiras, as well as the presence of impermeable subsurface soils that restrict outflows, rendering evaporation the sole mechanism for water to leave the system (Barbiéro et al., 2008; Furian et al., 2013; Assine et al., 2015a). Locally, the presence of the cordilheiras, which are vegetated sand ridges that stand 3-5 $\mathrm{m}$ above the lake surface, act as natural barriers to flood waters that drain the area during the austral summer. Both Soares et al. (2003) and de Santos et al. (2012) suggested that the isolation promoted by cordilheiras and the lack of surface water inflows are important controls on salina development. These processes are important to the completeness of late Holocene strata exhibited by some salinas, as flood water discharged across the surface of Lower Nhecolândia in vazantes can be erosive (McGlue et al., 2017). A second critical local factor promoting the evolution of the salinas is the presence and distribution of chemically cemented shallow floodplain soils. Several authors have suggested that topographically irregular cemented loams prevent groundwater from flowing through certain areas of the floodplain, thereby influencing the water balance of lakes occupying overlying localized depressions (Barbiéro et al., 2002; Furian et al., 2013). According to these authors, a unique geochemical family of waters evolves into saline-alkaline types through evaporation. In this model, the water that recharges the system comes from rainfall and groundwater inflows. In fact, $\delta^{18} \mathrm{O}$ and $\delta \mathrm{D}$ measures on water samples from groundwater, baías, and salinas in Nhecolândia (Almeida et al., 2009, 2010) reveal the influence of subsurface flows from baías into the salinas, which concentrate through evaporation because subsurface outflows are blocked by the 
chemically cemented soils (Barbiéro et al., 2007). In sum, lake alkalinization and salinization in Nhecolândia can be regarded as a long-term process, reliant on both water availability and basin isolation by floodplain soils and landforms.

\section{Conclusions}

This study provides the first integrated use of paleoecology to understand late Quaternary environmental change in Nhecolândia. Sponge and diatom microfossils recovered from a sediment core dated by ${ }^{14} \mathrm{C}$ and OSL revealed three important aquatic transitions that took place in the Holocene, which transformed Salina da Ponta into the salina that exists on the landscape today. The sediment-derived biological indicators showed that the lake passed through relatively fresh intervals in the early and middle Holocene, when climate in the southern Pantanal was dry relative to the present day. After $\sim 890 \pm 115$ cal year BP, salinity and alkalinity increased, leading to the collapse of the sponge fauna and a proliferation of benthic diatoms adapted to extreme lake water chemistry. The results show unequivocally that saline-alkaline lakes in Nhecolândia are not relict features of an ancient arid climate that affected the Pantanal. Rather, $\mathrm{pH}$ and salinity appear to have increased as water availability in the Pantanal increased over the past $1000 \mathrm{yrs}$, coupled with the evolution of local floodplain landforms and shallow soils.

Numerous studies have made it clear that the Pantanal is important to global biogeochemical cycles (particularly for the carbon cycle; Bastviken et al., 2010). Major changes in air temperature or the water cycle within large tropical wetlands are particularly worrisome, as variability in $\mathrm{CH}_{4}$ and $\mathrm{CO}_{2}$ fluxes, i.e., transitions from sink to source, could act as feedbacks that amplify the negative effects of climate change (Shindell, 2004). At the regional scale, the wetlands are socioeconomically vital, providing a host of ecosystem services to the local population, including fertile agricultural lands, ranching, transportation, and recreation, not to mention a readily available protein source through its fish stocks (Seidl \& Moraes, 2000), and the use of river-driven macrophytes as a source of biomass for power production (Buller et al., 2015). Many climate models predict that significant changes to tropical water cycles will accompany global warming, with the potential to increase the frequency of floods and droughts. The Pantanal's frontier setting and paucity of infrastructure renders its growing population vulnerable to severe climate events (e.g., prolonged droughts) that could alter wetland hydrology and degrade ecosystem services (Ioris et al., 2014; Junk et al., 2014; Marengo et al., 2016). The results of our study illustrate that the chemistry of Salina da Ponta evolved dynamically in the late Holocene. Such changes in lake chemistry have implications for greenhouse gases, as experiments have shown that salinas are $\mathrm{CO}_{2}$ sinks and minor $\mathrm{CH}_{4}$ sources, whereas baías are sources for both $\mathrm{CH}_{4}$ and $\mathrm{CO}_{2}$ (Bergier et al., 2014).

Acknowledgements The authors are grateful to the São Paulo Research Foundation (FAPESP) for financial support of this project (Grant \#2014/06889-2). We thank the National Council for Scientific and Technological Development (CNPq) for research grants to LVW and MLA (grant \#308563/2013-1) and to SAFSC (Grant \#476020/2013-1), Coordenação de Aperfeiçoamento de Pessoal de Nível Superior (Capes) for a doctorate scholarship to RLG, the University of Kentucky Vice President for Research for a seed grant to MM. We are grateful to the Luminescence and Gamma Spectrometry Laboratory at the University of São Paulo for access to optically stimulated luminescence dating facilities. We thank EMBRAPA-Pantanal for facilitating fieldwork. Dr. Fabiano Pupim (USP) and Dr. Aguinaldo Silva (UFMS) are gratefully acknowledged for their collaboration. We thank Dr. Karlyn Westover for assistance with constrained cluster analyses of the diatom data. The authors appreciate comments by the reviewers on an early version of the manuscript.

\section{References}

Ab'Sáber, A. N., 1988. O Pantanal Mato-grossense e a teoria dos refúgios. Revista Brasileira de Geografia 50: 9-57.

Aitken, M. J., 1985. Thermoluminescence Dating. Academic Press, London.

Alho, C. J. R., 2008. Biodiversity of the Pantanal: response to seasonal flooding regime and to environmental degradation. Brazilian Journal of Biology 68: 957-966.

Almeida, T. I. R., A. C. Paranhos Filho, M. M. da Rocha, G. F. De Souza, J. B. Sigolo \& R. A. Bertolo, 2009. As diferenciadas altitudes do nível da água dos lagos salinoalcalinos e hipossalinos do Pantanal da Nhecolândia: um indicativo de funcionamento do mega sistema lacustre. Geociências 28: 401-415.

Almeida, T. I. R., I. Karmann, A. C. Paranhos Filho, J. B. Sígolo \& R. A. Bertolo, 2010. Os diferentes graus de isolamento da água subterrânea como origem de sua variabilidade: Evidências isotópicas, hidroquímicas e da variação sazonal do nível da água no pantanal da Nhecolândia. Geologia USP 10: 37-47. 
Assine, M. L., 2005. River avulsions on the Taquari megafan, Pantanal wetland, Brazil. Geomorphology 70: 357-371.

Assine, M. L. \& P. C. Soares, 2004. Quaternary of the Pantanal, west-central Brazil. Quaternary International 114: 23-34.

Assine, M. L., E. R. Merino, F. N. Pupim, L. V. Warren, R. L. Guerreiro \& M. M. McGlue, 2015a. Geology and geomorphology of the Pantanal basin. In Bergier, I. \& M. L. Assine (eds), Dynamics of the Pantanal Wetland in South America. Springer, Cham: 23-50.

Assine, M. L., E. R. Merino, F. N. do Pupim, H. A. de Macedo \& M. G. M. dos Santos, 2015b. The quaternary alluvial systems tract of the Pantanal Basin, Brazil. Brazilian Journal of Geology 45: 475-489.

Assine, M. L., H. A. Macedo, J. C. Stevaux, I. Bergier, C. R. Padovani \& A. Silva, 2015c. Avulsive rivers in the hydrology of the Pantanal wetland. In Bergier, I. \& M. L. Assine (eds), Dynamics of the Pantanal Wetland in South America. Springer, Cham: 83-110.

Barbiéro, L., A. R. Filho, S. A. C. Furquim, S. Furian, A. Y. Sakamoto, V. Vallès, R. C. Graham, M. Fort, R. P. D. Ferreira \& J. P. Queiroz Neto, 2008. Soil morphological control on saline and freshwater lake hydrogeochemistry in the Pantanal of Nhecolândia, Brazil. Geoderma 148: 91-106.

Barbiéro, L., J. P. Queiroz Neto, G. Ciornei, A. Y. Sakamoto, B. Capellari, E. Fernandes \& V. Valles, 2002. Geochemistry of water and ground water in the Nhecolândia, Pantanal of Mato Grosso, Brazil: variability and associated processes. Wetlands 22: 528-540.

Barbiéro, L., S. A. C. Furquim, V. Vallès, S. Furian, A. Y. Sakamoto, A. Filho \& M. Fort, 2007. Natural arsenic in groundwater and alkaline lakes at the upper Paraguay basin, Pantanal, Brazil. Arsenic in Soil and Groundwater Environment 9: 101-126.

Bastviken, D., A. L. Santoro, H. Marotta, L. Q. Pinho, D. F. Calheiros, P. Crill \& A. Enrich-Prast, 2010. Methane emissions from Pantanal, South America, during the low water season: toward more comprehensive sampling. Environmental Science \& Technology 44: 5450-5455.

Battarbee, R. W., V. J. Jones, R. J. Flower, N. G. Cameron, H. Bennion, L. Carvalho \& S. Juggins, 2001. Diatoms. In Smol, J. P., H. J. B. Birks \& W. M. Last (eds), Tracking Environmental Change Using Lake Sediments, Vol. 3., Terrestrial, Algal, and Siliceous Indicators Kluwer Academic Publishers, Dordrecht: 155-202.

Bergier, I., A. Krusche \& F. Guérin, 2014. Alkaline lake dynamics in the Nhecolândia Landscape. In Bergier, I. \& M. L. Assine (eds), Dynamics of the Pantanal Wetland in South America. Springer International Publishing, Cham: $145-161$.

Bertaux, J., F. Sondag, R. Santos, F. Soubiès, C. Causse, V. Plagnes, F. Le Cornec \& A. Seidel, 2002. Paleoclimatic record of speleothems in a tropical region: study of laminated sequences from a Holocene stalagmite in CentralWest Brazil. Quaternary International 89: 3-16.

Blaauw, M. \& A. Cristen, 2011. Flexible paleoclimate age-depth models using an autoregressive gamma process. Bayesian Analysis 6: 457-474.

Bonetto, A. A. \& I. E. de Drago, 1966. Nuevos aportes al conocimiento de las esponjas argentinas. Physis 26: 129-140.
Braun, E. W., 1977. Cone aluvial do Taquari, unidade geomórfica marcante da planície quaternária do Pantanal. Revista Brasileira de Geografia 39: 164-180.

Buller, L. S., E. Ortega, I. Bergier, J. M. Mesa-Pérez, S. M. Salis \& C. A. Luengo, 2015. Sustainability assessment of water hyacinth fast pyrolysis in the Upper Paraguay River basin, Brazil. Science of the Total Environment 532: 281-291.

Clapperton, C. M., 1993. Nature of environmental changes in South America at the Last Glacial Maximum. Palaeogeography, Palaeoclimatology, Palaeoecology 101: 189-208.

Colinvaux, P. A., P. E. De Oliveira \& M. B. Bush, 2000. Amazonian and neotropical plant communities on glacial time-scales: the failure of the aridity and refuge hypotheses. Quaternary Science Reviews 19: 141-169.

Costa, M. P. F., K. H. Telmer, T. L. Evans, T. I. R. Almeida \& M. T. Diakun, 2015. The lakes of the Pantanal: inventory, distribution, geochemistry, and surrounding landscape. Wetlands Ecology and Management 23: 19-39.

De Deckker, P., 1983. Australian salt lakes their history, chemistry, and biota a review. Hydrobiologia 105: 231-244.

de Oliveira, M. D. \& D. F. Calheiros, 2000. Flood pulse influence on phytoplankton communities of the south Pantanal floodplain, Brazil. Hydrobiologia 427: 101-112.

Debrot, A. O. \& R. W. M. Van Soest, 2001. First records of the freshwater sponges Corvoheteromeyenia heterosclera and Spongilla alba (Porifera: Spongillidae) from Curaçao, with species descriptions and data from transplantation experiments. Caribbean Journal of Science 37: 88-94.

Evans, T. L., \& M. P. F. Costa, 2013. Landcover classification of the Lower Nhecolândia subregion of the Brazilian Pantanal Wetlands using ALOS/PALSAR, RADARSAT-2 and ENVISAT/ASAR imagery, Vol. 128. Remote Sensing of Environment Elsevier Inc, Lanham: 118-137.

Ezcurra de Drago, I., 1974. Las especies sudamericanas de Corvomeyenia Weltner (Porifera, Spongillidae). Physis 33: 233-240.

Ezcurra de Drago, I., 1979. Un nuevo genero sudamericano de esponjas: Corvoheteromeyenia gen. nov. (Porifera: Spongillidae). Neotropica 25: 109-118.

Fornace, K. L., B. S. Whitney, V. Galy, K. A. Hughen \& F. E. Mayle, 2016. Late Quaternary environmental change in the interior South American tropics: new insight from leaf wax stable isotopes. Earth and Planetary Science Letters 438: 75-85.

Fritz, S. C., S. Juggins \& R. W. Batterbee, 1993. Diatom assemblages and ionic characterization of lakes of the northern great plains, North America - a tool for reconstructing past salinity and climate fluctuations. Canadian Journal of Fisheries and Aquatic Sciences 50: 1844-1856.

Furian, S., E. R. C. Martins, T. M. Parizotto, A. T. RezendeFilho, R. L. Victoria \& L. Barbiéro, 2013. Chemical diversity and spatial variability in myriad lakes in Nhecolândia in the Pantanal wetlands of Brazil. Limnology and Oceanography 58: 2249-2261.

Furquim, S. A. C., R. C. Graham, L. Barbiéro, J. P. Queiroz Neto \& P. Vidal-Torrado, 2010. Soil mineral genesis and distribution in a saline lake landscape of the Pantanal Wetland, Brazil. Geoderma 154: 518-528. 
Girard, P., I. Fantin-Cruz, S. M. L. De Oliveira \& S. K. Hamilton, 2010. Small-scale spatial variation of inundation dynamics in a floodplain of the Pantanal (Brazil). Hydrobiologia 638: 223-233.

Guerreiro, R. L., J. C. Stevaux, M. Parolin \& M. L. Assine, 2013. Late Pleistocene and Holocene paleoenvironments in ponds and alluvial sediments of Upper Paraná River, Brazil. Revista Brasileira de Paleontologia 16: 39-46.

Hamilton, S. K., S. J. Sippel \& J. M. Melack, 1996. Inundation patterns in the Pantanal wetland of South America determined from passive microwave remote sensing. Archiv für Hydrobiologie 137: 1-23.

Hogg, A., Q. Hua, P. G. Blackwell, M. Niu, C. E. Buck, T. P. Guilderson, T. J. Heaton, J. G. Palmer, P. J. Reimer, R. W. Reimer, C. S. M. Turney \& S. R. H. Zimmerman, 2013. SHCal13 Southern Hemisphere calibration, 0-50,000 Years cal BP. Radiocarbon 55: 1889-1903.

Houk, V., R. Klee \& H. Tanaka, 2010. Atlas of freshwater centric diatoms with a brief key and descriptions Part III. Stephanodiscaceae A: Cyclotella, Tertiarius, Discostella. Fottea 10(Supplement): 1-498.

Hua, Q., M. Barbetti \& A. Z. Rakoeski, 2013. Atmospheric radiocarbon for the period 1950-2010. Radiocarbon 55: 2059-2072.

Ioris, A. A. R., C. T. Irigaray \& P. Girard, 2014. Institutional responses to climate change: opportunities and barriers for adaptation in the Pantanal and the Upper Paraguay River Basin. Climatic Change 127: 139-151.

Juggins, S., 2016. Rioja: Analysis of Quaternary Science Data, version 0.9-9, https://CRAN.R-project.org/package=rioja.

Junk, W. J., P. B. Bayley \& R. E. Sparks, 1989. The flood pulse concept in river-floodplain systems. Canadian Special Publication of Fisheries and Aquatic Sciences 106: 110-127.

Junk, W. J., C. N. da Cunha, K. M. Wantzen, P. Petermann, C. Strüssmann, M. I. Marques \& J. Adis, 2006. Biodiversity and its conservation in the Pantanal of Mato Grosso, Brazil. Aquatic Sciences 68: 278-309.

Junk, W. J., M. T. F. Piedade, R. Lourival, F. Wittmann, P. Kandus, L. D. Lacerda, R. L. Bozelli, F. A. Esteves, C. N. da Cunha, L. Maltchik, J. Schöngart, Y. Schaeffer-Novelli \& A. A. Agostinho, 2014. Brazilian wetlands: their definition, delineation, and classification for research, sustainable management, and protection. Aquatic Conservation: Marine and Freshwater Ecosystems 24: $5-22$.

Klammer, G., 1982. Die Paläowüste des Pantanal von Mato Grosso und die pleistozäne Klimageschichte der brasilianischen Randtropen. Zeitschrift für Geomorphologie 26: 393-416.

Kuerten, S., M. Parolin, M. L. Assine \& M. M. McGlue, 2013. Sponge spicules indicate Holocene environmental changes on the Nabileque River floodplain, southern Pantanal, Brazil. Journal of Paleolimnology 49: 171-183.

Machado, V. D. E. S., C. Volkmer-ribeiro \& R. Iannuzzi, 2012. Inventary of the sponge fauna of the Cemitério Paleolake, Catalão, Goiás, Brazil. Anais da Academia Brasileira de Ciências 84: 17-34.

Malone, C. F. S., K. R. D. S. Santos, M. J. Neto \& A. Y. Sakamoto, 2007. Gêneros de Algas no Plâncton de Lagoas Salinas Situadas na Fazenda Nhumirim, Pantanal da Nhecolândia, MS. Revista Brasileira de Biociências 5: 588-590.

Malone, C. F. S., K. R. S. de Santos \& C. L. Sant'Anna, 2012. Algas e cianobactérias de ambientes extremos do Pantanal brasileiro. Oecologia Australis 16: 745-755.

Manconi, R. \& R. Pronzato, 2002. Suborder Spongillina subord. nov.: freshwater sponges. Systema Porifera: A Guide to the Classification of Sponges 1: 921-1021.

Manconi, R. \& R. Pronzato, 2007. Gemmules as a key structure for the adaptive radiation of freshwater sponges: a morphofunctional and biogeographical study. Museu Nacional Serie Livros 28: 61-77.

Marani, L. \& P. C. Alvala, 2007. Methane emissions from lakes and floodplains in Pantanal, Brazil. Atmospheric Environment 41: 1627-1633.

Marengo, J. A., L. M. Alves \& R. R. Torres, 2016. Regional climate change scenarios in the Brazilian Pantanal watershed. Climate Research 68(2-3): 201-213.

Mayle, F. E., R. Burbridge \& T. J. Killeen, 2000. Millennialscale dynamics of southern Amazonian rain forests. Science 290: 2291-2294.

McGlue, M. M., A. Silva, F. A. Corradini, H. Zani, M. A. Trees, G. S. Ellis, M. Parolin, P. W. Swarzenski, A. S. Cohen \& M. L. Assine, 2011. Limnogeology in Brazil's "forgotten wilderness": a synthesis from the large floodplain lakes of the Pantanal. Journal of Paleolimnology 46: 273-289.

McGlue, M. M., A. Silva, H. Zani, F. A. Corradini, M. Parolin, E. J. Abel, A. S. Cohen, M. L. Assine, G. S. Ellis, M. Trees, S. Kuerten, F. D. S. Gradella \& G. G. Rasbold, 2012. Lacustrine records of Holocene flood pulse dynamics in the Upper Paraguay River watershed (Pantanal wetlands, Brazil). Quaternary Research 78: 285-294.

McGlue, M. M., A. Silva, M. L. Assine, J. Stevaux \& F. Pupim, 2015. Paleolimnology in the Pantanal: using lake sediments to track quaternary environmental change in the world's largest tropical wetland. In Bergier, I. \& M. L. Assine (eds), Dynamics of the Pantanal Wetland in South America. Springer, Switzerland: 51-81.

McGlue, M. M., R. L. Guerreiro, I. Bergier, A. Silva, F. N. Pupim, V. Oberc \& M. L. Assine, 2017. Holocene stratigraphic evolution of saline lakes in Nhecolândia, southern Pantanal wetlands (Brazil). Quaternary Research. https://doi.org/10.1017/qua.2017.57.

Metzeltin, D. \& H. Lange-Bertalot, 2007. Tropical diatoms of South America II. Special remarks on biogeographic disjunction. Iconographia Diatomologica 18: 1-877.

Morales, E. A., C. E. Wetzel, S. F. Rivera, M. H. Novais, L. Hoffmann \& L. Ector, 2014. Craticula strelnikoviana sp. nov. and Craticula guaykuruorum sp. nov. (Bacillariophyta) from South American saline lakes. Nova Hedwigia 143: 223-237.

Mourão, G. H., I. H. Ishii \& Z. Campos, 1988. Alguns fatores limnológicos relacionados com a ictiofauna de baías e salinas do Pantanal da Nhecolândia, Mato Grosso do Sul, Brasil. Acta Limnologica Brasiliensia 11: 181-198.

Murray, A. S. \& A. G. Wintle, 2003. The single aliquot regenerative dose protocol: potential for improvements in reliability. Radiation Measurements 37: 377-381.

Novello, V. F., M. Vuille, F. W. Cruz, N. M. Stríkis, M. S. de Paula, R. L. Edwards, H. Cheng, I. Karmann, P. F. Jaqueto, R. I. F. Trindade, G. A. Hartmann \& J. S. Moquet, 2016. 
Centennial-scale solar forcing of the South American Monsoon System recorded in stalagmites. Scientific Reports 6: 24762.

Novello, V. F., F. W. Cruz, M. Vuille, N. M. Stríkis, R. L. Edwards, H. Cheng, S. Emerick, M. S. de Paula, X. Li, E. de S. Barreto, I. Karmann \& R. V. Santos, 2017. A high-resolution history of the South American Monsoon from Last Glacial Maximum to the Holocene. Scientific Reports 7: 44267

Nunes da Cunha, C. \& W. J. Junk, 2001. Distribution of woody plant communities along the flood gradient in the Pantanal of Poconé, Mato Grosso, Brazil. International Journal of Ecology and Environmental Sciences 27: 63-70.

Parolin, M., C. Volkmer-Ribeiro \& J. C. Stevaux, 2007. Sponge spicules in peaty sediments as paleoenvironmental indicators of the Holocene in the Upper Paraná River, Brazil. Revista Brasileira de Paleontologia 10: 17-26.

Parolin, M., C. Volkmer-Ribeiro \& J. C. Stevaux, 2008. Use of spongofacies as a proxy for river-lake paleohydrology in Quaternary deposits of central-western Brazil. Revista Brasileira de Paleontologia 11: 187-198.

Por, F. D., 1995. The Pantanal of Mato Grosso (Brazil): World's Largest Wetlands. Springer, Dordrecht.

Pott, A. \& J. S. V. Silva, 2015. Terrestrial and aquatic vegetation diversity of the Pantanal wetland. In Bergier, I. \& M. L. Assine (eds), Dynamics of the Pantanal Wetland in South America. Springer, Switzerland: 111-131.

Racek, A. A., 1969. The freshwater sponges of australia (Porifera: Spongillidae). Australian Journal of Marine and Freshwater Research 20: 267-310.

Racek, A. A., 1974. The waters of Merom: a study of lake Huleh. IV Spicular remains of fresh-water sponges (Porifera). Archiv für Hydrobiologie 74: 137-158.

Salis, S. M., C. R. Lehn, P. P. Mattos, I. Bergier \& S. M. A. Crispim, 2014. Root behavior of savanna species in Brazil's Pantanal wetland. Global Ecology and Conservation 2: $378-384$.

de Santos, K. R. S. \& C. L. Sant'anna, 2010. Cianobactérias de diferentes tipos de lagoas ("salina", "salitrada" e "baía") representativas do Pantanal da Nhecolândia, MS, Brasil. Brazilian Journal of Botany 33: 61-83.

de Santos, K. R. S., A. C. R. da Rocha \& C. L. Sant'Anna, 2012. Diatoms from shallow lakes in the Pantanal of Nhecolândia, Brazilian wetland. Oecologia Australis 16: 756-769.

Sawakuchi, A. O., V. R. Mendes, F. do N. Pupim, T. D. Mineli, L. M. A. L. Ribeiro, A. Zular, C. C. F. Guedes, P. C. F. Giannini, L. Nogueira, W. Sallun Filho \& M. L. Assine, 2016. Optically stimulated luminescence and isothermal thermoluminescence dating of high sensitivity and well bleached quartz from Brazilian sediments: from Late Holocene to beyond the Quaternary? Brazilian Journal of Geology 46: 209-226.

Schnurrenberger, D., J. Russell \& K. Kelts, 2003. Classification of lacustrine sediments based on sedimentary components. Journal of Paleolimnology 29: 141-154.

Seidl, A. F. \& A. S. Moraes, 2000. Global valuation of ecosystem services: application to the Pantanal da Nhecolandia, Brazil. Ecological Economics 33: 1-6.
Shindell, D. T., 2004. Impacts of climate change on methane emissions from wetlands. Geophysical Research Letters 31: L21202.

Soares, A. P., P. C. Soares \& M. L. Assine, 2003. Areiais e lagoas do Pantanal, Brasil: herança paleoclimática? Revista Brasielira de Geociencias 33: 211-224.

Tapia, P. M., S. C. Fritz, P. A. Baker, G. O. Seltzer \& R. B. Dunbar, 2003. A late Quaternary diatom record of tropical climate history from Lake Titicaca (Peru and Bolivia). Palaeogeography, Palaeoclimatology, Palaeoecology 194: 139-164.

Tavares, M. C. M., V. R. Cecília \& R. de Rosa-Barbosa, 2003. Primeiro registro de Corvoheteromeyenia australis (Bonetto \& Ezcurra de Drago) para o Brasil com chave taxonômica para os poríferos do Parque Estadual Delta do Jacuí, Rio Grande do Sul, Brasil. Revista Brasileira de Zoologia 20: 169-182.

Tremarin, P. I., T. A. V. Ludwig \& L. C. Torgan, 2014. Four new Aulacoseira species (Coscinodiscophyceae) from Matogrossense Pantanal, Brazil. Diatom Research 29: 183-199.

Tricart, J., 1982. El pantanal: un ejemplo del impacto geomorfologico sobre el ambiente. Informativo Geografico Chile 29: 81-97.

Van Soest, R. W. M., N. Boury-Esnault, J. N. A. Hooper, K. Rützler, N. J. de Voogd, B. Alvarez, E. Hajdu, A. B. Pisera, R. Manconi, C. Schönberg, M. Klautau, B. Picton, M. Kelly, J. Vacelet, M. Dohrmann, M. C. Díaz, P. Cárdenas, J. L. Carballo, P. Rios \& R. Downey, 2017. World Porifera database. Accessed at http://www.marinespecies.org/ porifera on 2017-10-02.

Valverde, O., 1972. Fundamentos geográficos do planejamento do Município de Corumbá. Revista Brasileira de Geografia 34: 49-144.

Volkmer-Ribeiro, C., 1992. The freshwater sponges in some peat-bog ponds in Brazil. Amazoniana 12: 317-335.

Volkmer-Ribeiro, C. \& V. D. S. Machado, 2007. Freshwater sponges (Porifera, Demospongiae) indicators of some coastal habitats in South America: redescriptions and key to identification. Iheringia. Série Zoologia 97: 157-167.

Volkmer-Ribeiro, C. \& J. F. M. Motta, 1995. Esponjas formadas de espongilitos em lagoas do Triangulo Mineiro e adjascências, com indicação da preservação de habitat. Biociências 3: 145-168.

Volkmer-Ribeiro, C. \& M. Parolin, 2010. As esponjas In Parolin, M., C. Volkmer-Ribeiro, \& J. A. Leandrini (eds), Abordagem ambiental interdisciplinar em bacias hidrográficas no Estado do Paraná. Editora da Fecilcam, Campo Mourão-PR: 105-130.

Volkmer-Ribeiro, C. \& S. M. Pauls, 2000. Esponjas de Agua Dulce (Porifera, Demospongiae) de Venezuela. Acta Biologica Venezuelica Cararas 20: 1-28.

Volkmer-Ribeiro, C. \& B. Turcq, 1996. SEM analysis of silicious spicules of a freshwater sponge indicate paleoenvironmental changes. Acta Microscópica 5: 186-187.

Volkmer-Ribeiro, C., J. F. M. Motta \& V. L. M. Callegaro, 1998. Taxonomy and distribution of Brazilian spongillites. In Watanabe, Y. \& N. Fusetani (eds), Sponge Sciences: Multidisciplinary Perspectives. Springer, Tokyo: 271-278.

Volkmer-Ribeiro, C., M. M. F. Correia, S. L. A. Brenha \& M. A. Mendonça, 1999. Freshwater sponges from a 
neotropical sand dune area. Memoirs of the Queensland Museum 44: 643-649.

Volkmer-Ribeiro, C., D. M. Marques, R. De Rosa-Bar-bosa \& V. S. Machado, 2004. Sponge spicules in sediments indicate evolution of coastal freshwater bodies. Journal of Coastal Research 39: 469-472.

Volkmer-Ribeiro, C., I. E. de Drago \& M. Parolin, 2007. Spicules of the freshwater sponge Ephydatia facunda indicate lagoonal paleoenvironment at the pampas of Buenos Aires Province, Argentina. Journal of Coastal Research 50: 449-452.

Whitney, B. S., F. E. Mayle, S. W. Punyasena, K. A. Fitzpatrick, M. J. Burn, R. Guillen, E. Chavez, D. Mann, R.
T. Pennington \& S. E. Metcalfe, 2011. A 45kyr palaeoclimate record from the lowland interior of tropical South America. Palaeogeography, Palaeoclimatology, Palaeoecology 307: 177-192.

Zani, H., M. L. Assine \& M. M. McGlue, 2012. Remote sensing analysis of depositional landforms in alluvial settings: method development and application to the Taquari megafan, Pantanal (Brazil). Geomorphology 161-162: 82-92.

Zhou, J. \& K. M. Lau, 1998. Does a monsoon climate exist over South America? Journal of Climate 11: 1020-1040. 